\title{
The contribution of foliar micromorphology and anatomy to the circumscription of species within the Chusquea ramosissima informal group (Poaceae, Bambusoideae, Bambuseae)
}

\author{
Thales D. Leandro ${ }^{1}$ (D) $\cdot$ Vera L. Scatena ${ }^{1}$ Lynn G. Clark $^{2}$
}

Received: 12 August 2016/Accepted: 15 March 2017/Published online: 7 April 2017

(C) Springer-Verlag Wien 2017

\begin{abstract}
Chusquea is a diverse but monophyletic genus of Neotropical woody bamboos from primarily montane forests that comprises four well-supported lineages: subg. Magnifoliae, subg. Platonia, subg. Rettbergia, and the Euchusquea clade (comprising subg. Swallenochloa and subg. Chusquea). However, the relationships among clades or taxa within the Euchusquea clade inferred from molecular data are mostly not congruent with those inferred from morphological evidence, consequently limiting our ability to understand species relationships. In this study we generated foliar micromorphological and anatomical data for the Chusquea ramosissima informal group (Chusquea ramosissima, C. tenella, and C. tenuiglumis), and for the putative new species from Bolivia in this group, in order to test the value of these types of data for defining species and to seek potential synapomorphies for this group. Our results demonstrate that epidermal features, mainly with regard to the stomatal apparatus, proved to be more valuable in distinguishing species than anatomical characters. The presence of horizontally elongated silica cells over the veins and adaxial arm cells with invaginations from the abaxial side was shared by all the studied species but is not unique to this group. The type of trichomes, shape of silica bodies, type of arm cells, and midrib structure may be useful to lesser degree. All four species exhibited
\end{abstract}

Handling editor: Mike Thiv.

Thales D. Leandro

thaleshdias@gmail.com

1 Departamento de Botânica, Universidade Estadual Paulista, Av. 24A, 1515, Rio Claro, SP 13506-900, Brazil

2 Department of Ecology, Evolution, and Organismal Biology, Iowa State University, Ames, IA 50011-1020, USA intraspecific variation in development of the papillae on the long cells. Support for the recognition of the new species from Bolivia is provided by micromorphological characters. An identification key based on leaf blade features is provided for the four studied species.

Keywords Chusqueinae · Leaf · Monocotyledons · Poales · Woody bamboos

\section{Introduction}

Bambuseae comprise one of three lineages within Bambusoideae and include at least 812 species in 66 genera (Clark et al. 2015). This tribe is mostly diversified in tropical forests, both lowland and montane, and mostly in relatively humid habitats (Judziewicz et al. 1999; Clark et al. 2015). Two major lineages are currently recognized for Bambuseae based on molecular data (Sungkaew et al. 2009; Kelchner and BPG 2013): Paleotropical woody bamboos (seven subtribes, 407+ species), and Neotropical woody bamboos (three subtribes, 405+ species) (BPG 2012; Clark et al. 2015; Wong et al. 2016). The phylogenetic relationship of the three subtribes within the Neotropical woody bamboos [(Arthrostylidiinae + Guaduinae) + Chusqueinae] has good support (Kelchner and BPG 2013; Wysocki et al. 2015), although no defining characters have been identified for the Neotropical clade (Clark et al. 2015). Sister to each other, Arthrostylidiinae and Guaduinae are each well supported as monophyletic based on morphological and molecular data (Ruiz-Sanchez 2011; Tyrrell et al. 2012; Kelchner and BPG 2013), while the monophyly of Chusqueinae, which includes only the genus Chusquea Kunth, is based primarily on molecular evidence although all members share 
the presence of two papillae per subsidiary cell and oneflowered spikelets with four glumes and no rachilla extension (Fisher et al. 2009, 2014; Kelchner and BPG 2013).

Chusquea is the most diverse genus of Neotropical woody bamboos, comprising more or less 175 described species primarily from montane forests with some inhabiting high elevation grassland formations (Judziewicz et al. 1999; Fisher et al. 2014). Plastid sequence data support the existence of four clades within Chusquea (Fisher et al. 2009, 2014): (1) subg. Magnifoliae; (2) subg. Platonia; (3) subg. Rettbergia; and (4) the major Euchusquea clade, comprising subg. Swallenochloa and subg. Chusquea, and including about $75 \%$ of the species diversity of the genus. However, inferring relationships within the Euchusquea clade with confidence remain a challenge because its morphological-based subgeneric and sectional classification (Clark 1989; Fisher et al. 2009, 2014) is largely incongruent with the molecular topology. On the other hand, the Chusquea ramosissima informal group, which is distinguished by a unique combination of morphological characters within the Euchusquea clade, also was supported in the molecular phylogeny (Fisher et al. 2009, 2014).

The $C$. ramosissima informal group, defined by the presence of culm leaves with pseudopetiolate, deciduous blades that usually remain green and racemose or weakly paniculate synflorescences, consists of $C$. ramosissima Lindman, C. tenella Nees, and C. tenuiglumis Döll (Fisher et al. 2009, 2014). These species are distributed in Argentina, Bolivia, Brazil, Paraguay, and Uruguay, and occupy Atlantic or montane forests from sea level to $1200 \mathrm{~m}$ in elevation (Judziewicz et al. 1999). Previously, these three species were included within subg. Rettbergia (Judziewicz et al. 1999); however, Fisher et al. (2009, 2014) and Mota (2013) excluded them from subg. Rettbergia and placed them within subg. Chusquea, based on their infravaginal branching and the more or less constellate arrangement of subsidiary buds with respect to the central bud (Clark 2004), as well as the unambiguous resolution of $C$. ramosissima and $C$. tenella within the Euchusquea clade based on plastid data.

Woody bamboos grow vegetatively for long periods, and then their life cycle usually ends after a single gregarious flowering episode (Seifriz 1950; Janzen 1976; Judziewicz et al. 1999; Ruiz-Sanchez et al. 2017). For this reason, vegetative morphological data from rhizomes, culms, branches, and leaves remain extremely important for bamboo studies. Anatomical and micromorphological surveys in addition to morphological ones have established the importance of these types of features in providing the basis for a more natural classification within the grass family (e.g., Guglieri et al. 2008; Oliveira et al. 2008; Gomes and Neves 2009; Pelegrin et al. 2009; Aliscioni et al. 2016; Leandro et al. 2016a, b). Although diagnosable macro-morphological characters of Chusquea and its subgenera have been identified (Fisher et al. 2009, 2014), there is a lack of knowledge with respect to the value of leaf blade anatomical and micromorphological features across the genus, even considering the amount of data available in the literature (e.g., Clark 1986, 1990; Clark et al. 1989; Montti et al. 2008, 2009; Guerreiro et al. 2013; Lizarazu 2013).

Thus, considering the incongruence between the chloroplast phylogeny versus the morphology-based classification of the Euchusquea clade, and the need for anatomical and micromorphological studies in the genus, the main objective of the current work was to examine leaf blade micromorphology and anatomy and test their value for circumscription across species within the morphologically based $C$. ramosissima informal group (Fisher et al. 2009, 2014). To that end, C. ramosissima, C. tenella, and C. tenuiglumis were studied. We also included a putative undescribed species of Chusquea from Bolivia that belongs to this group and is morphologically similar to $C$. ramosissma.

\section{Materials and methods}

\section{Taxon sampling}

The following three species comprising the $C$. ramosissima informal group (Fisher et al. 2009, 2014) were studied: $C$. ramosissima, C. tenella, and C. tenuiglumis. Chusquea ramosissima is widely distributed in Argentina, Bolivia, Brazil, Paraguay, and Uruguay, C. tenella occurs in Argentina, Brazil and Uruguay, and C. tenuiglumis is endemic to Brazil. Depending on available material, we balanced sampling to represent the geographic ranges of these species as well multiple populations in relative proximity (Table 1), but we did not include any material from Uruguay as the only available specimens were not in good condition. We also included three samples of a putative new species from Bolivia referred to as Chusquea sp. nov. (Table 1). The observation of specimens using scanning electron microscopy (SEM) or light microscopy (LM) is indicated in Table 2.

Material for both micromorphology and anatomy was taken from fully expanded leaf blades in the middle of the branch complement, from either sterile or fertile herbarium specimens. For both $C$. ramosissima and $C$. tenella, a majority of available specimens were fertile, as bamboos tend to be collected by non-specialists only when in flower, but for each species, two or more sterile collections were also available and sampled. Available specimens for $C$. tenuiglumis and Chusquea sp. nov. were all sterile; the only 
Table 1 Voucher information for the four species of the Chusquea ramosissima informal group used in this study

\section{Chusquea ramosissima Lindm.}

BRAZIL. Paraná: Mun. Araucaria, margins of the floodplain of the Rio Iguaçu, near the bridge crossing of BR-476, Curitiba-Lapa, $880 \mathrm{~m}$ a. s. 1., 3 Mar 1991, Clark and Windisch 849 (ISC); Mun. Santa Helena Porto Verde, 12 Dec 1977 (fl), Hatschbach 40533 (US); Mun. Cerro Azul, Cab. Rib. do Tigre, 24 Jan 1980 (fl), Hatschbach 42746 (US). Rio Grande do Sul: Boa Vista, Salvador do Sul, 200 m a. s. 1., 22 Apr 1969, Klein 8307 (US). Rio de Janeiro: Mun. de Petŕopolis, Vale de Bom Sucesso, "Caixa de Agua”, 720 m a. s. 1., 6 May 1972, Soderstrom and Sucre 1986 (US). Santa Catarina: Santo Antônio, Itapiranga, 400 m a. s. 1., 20 Jan 1974, Klein and Klein 11041 (US). PARAGUAY. Dep. Guairá: Colonia Independencia, 1 Apr 1950, Anderson 1188 (US). Dep. Itapúa: Obligado, El Tirol, $19.5 \mathrm{~km}$ by road NNE of Encarnación, 6 Nov 1976, Foster 76-35 (US)

\section{Chusquea tenella Nees}

ARGENTINA. Misiones: Morro Sapucaia, 29 Jan 1948 (fl), Palacios-Cuezzo 474 (US). BRAZIL. Paraná: Campo Morão, 28 Mar-2 Apr 1946, Swallen 9004 (US). Rio Grande do Sul: Vila Manresa p. P. Alegre, 15 May 1950 (fl), Rambo 47076 (US). Santa Catarina: Morro do Rio Vermelho, 250 m a. s. 1., 27 Jun 1968 (fl), Klein and Bresolin 7766 (US); Palmas, Governador Celso Ramos, 100 m a. s. $1 ., 19$ May 1971 (fl), Klein and Bresolin 9477 (US). São Paulo: BR-116, ca. Km 515, about 38 km S of Jacupiranga, Braço Feio, Serra do Azeite, 400 m a. s. 1., 4 Mar 1990, Clark and Windisch 725 (ISC)

\section{Chusquea tenuiglumis Döll in Martius}

BRAZIL. Minas Gerais: Mun. Viçosa, municipal road from Viçosa to Araponga, 730 m a. s. 1., 25 Feb 1990, Clark and Morel 706 (ISC); Rio de Janeiro: Estrada Rio de Janeiro-Grumarí, 100 m a. s. 1., 23 Mar 1972, Soderstrom and Sucre 1918 (US); Santa Catarina: Mun. Petrolândia, 3 km before Petrolândia, 530 m a. s. 1., 5 Mar 1991, Clark and Windisch 864 (ISC)

\section{Chusquea sp. nov.}

BOLIVIA. Dep. La Paz, Prov. Franz Tamayo: Parque Nacional Madidi, camino de Apolo-Azariamas, Arroyo Pintata, a $495 \mathrm{~m}$ del campamento en dirección SE, aprox. 20 minutos saliendo del camino, $1011 \mathrm{~m}$ a. s. 1., 19 Feb 2003, Cayola et al. 6 (ISC); Parque Nacional Madidi, Chaquisapa, cerca al rio Mojos, $921 \mathrm{~m}$ a. s. 1., 9 Jul 2005, Fuentes et al. 9662 (ISC); Parque Nacional y Area Natural de Manejo Integrado Madidi, norte de Apolo, 940-1170 m a. s. 1., 7 Mar 2005, Uzquiano et al. 10 (MO)

ISC Ada Hayden Herbarium at Iowa State University; MO Herbarium at the Missouri Botanical Garden; US U.S. National Herbarium at the Smithsonian Institution

Table 2 List of Chusquea species, vouchers and their use in this study

\begin{tabular}{|c|c|c|c|}
\hline \multirow[t]{2}{*}{ Тaxa } & \multirow[t]{2}{*}{ Voucher } & \multicolumn{2}{|c|}{ Analysis performed } \\
\hline & & SEM & LM \\
\hline Chusquea ramosissima & Anderson 1188 & & $\mathrm{X}$ \\
\hline C. ramosissima & Hatschbach 40533 & $\mathrm{X}$ & $\mathrm{X}$ \\
\hline C. ramosissima & Foster 76-35 & $\mathrm{X}$ & \\
\hline C. ramosissima & Hatschbach 42746 & $\mathrm{X}$ & $\mathrm{X}$ \\
\hline C. ramosissima & Clark and Windisch 849 & & $X$ \\
\hline C. ramosissima & Soderstrom and Sucre 1986 & $\mathrm{X}$ & \\
\hline C. ramosissima & Klein 8307 & $\mathrm{X}$ & \\
\hline C. ramosissima & Klein and Klein 11041 & $\mathrm{X}$ & \\
\hline Chusquea tenella & Klein and Bresolin 9477 & & $X$ \\
\hline C. tenella & Klein and Bresolin 7766 & $\mathrm{X}$ & $\mathrm{X}$ \\
\hline C. tenella & Clark and Windisch 725 & & $X$ \\
\hline C. tenella & Swallen 9004 & $X$ & \\
\hline C. tenella & Palacios-Cuezzo 474 & $\mathrm{X}$ & \\
\hline C. tenella & Rambo 47076 & $\mathrm{X}$ & \\
\hline Chusquea tenuiglumis & Clark and Morel 706 & $\mathrm{X}$ & $X$ \\
\hline C. tenuiglumis & Clark and Windisch 864 & $X$ & $X$ \\
\hline C. tenuiglumis & Soderstrom and Sucre 1918 & & $X$ \\
\hline Chusquea sp. nov. & Fuentes et al. 9662 & $X$ & $X$ \\
\hline Chusquea sp. nov. & Cayola et al. 6 & $\mathrm{X}$ & $X$ \\
\hline Chusquea sp. nov. & Uzquiano et al. 10 & $X$ & $X$ \\
\hline
\end{tabular}

$L M$ light microscopy, SEM scanning electron microscopy 
flowering specimen of $C$. tenuiglumis is the type with limited leaf material, and thus we did not sample it.

\section{Micromorphology (SEM)}

Two pieces of approximately $0.5 \mathrm{~cm}^{2}$ of the middle portion of a fully expanded branch leaf were excised and attached to a cylindrical sample holder (stub) such that both adaxial and abaxial surfaces were exposed, and coated with a thin sample of gold (Denton vacuum Desk III). At least two specimens per species were submerged in xylene for approximately $10 \mathrm{~min}$, eliminating the epicuticular wax to provide a better view of micromorphological features (Dávila and Clark 1990). Observation and images of the surface view were obtained with the aid of a scanning electron microscope (JEOL JSM-5800LV) in the Microscopy and Nano-Imaging Facility (MNIF) at Iowa State University (ISU).

\section{Anatomy (LM)}

The middle portion of fully expanded branch leaves was excised and then immersed in polyethylene glycol 1.500 solution and kept in an incubator at $60{ }^{\circ} \mathrm{C}$ for fifteen days (adapted from Richter 1985). Cross sections were made using a Spencer 820 rotary microtome, and then they were cleared in $50 \%$ sodium hypochlorite, rinsed in distilled water, and stained in epoxy tissue stain (Spurlock et al. 1966). Semi-permanent slides were mounted in 50\% glycerin and analyzed under a light microscope (Olympus BX-40).

Leaf clearings were performed in order to describe the structures in surface view. For this purpose, pieces of approximately $0.5 \mathrm{~cm}^{2}$ from the middle portion of a fully expanded branch leaf were removed. These pieces were hydrated through a graded series of ethyl alcohol (50, 25 and $10 \%$ ) and then soaked in $1: 1 / \mathrm{dH}_{2} 0$ (deionized water) until the samples were translucent. Samples were rinsed with $\mathrm{dH}_{2} \mathrm{O}$, dehydrated through a graded series of ethyl alcohol $(25,50$, and $70 \%)$, and then stained with $1 \%$ safranin and $0.5 \%$ fast green in ethanol (adapted from Johansen 1940). Stained samples were treated with ethyl alcohol (95 and 100\%), washed with xylene and then with xylene and Permount (1:1). Permanent slides were mounted with Permount.

\section{Images and terminology}

For both sections and clearings, photomicrographs were obtained with the aid of a Zeiss Axio Observer microscope in the MNIF at ISU using ZEN 2.0 blue software, and applying different light contrast regimes. The terminology for the leaf blade in cross section and in surface view was primarily followed Ellis (1976, 1979), but updates in leaf blade terminology were considered as appropriate. The widely employed term "fusoid cells" was used as a proxy for the usually conspicuous intercellular spaces (often including cell wall remnants) produced by fusoid cell collapse during development as seen in cross section (Vega et al. 2016).

\section{Results}

The following data in tabular form are available upon request from the first author. A summary of the most informative micromorphological and anatomical features for each species is provided in Table 3.

\section{Epidermal surfaces (SEM and clearings)}

Data for epidermal cells as seen with scanning electron microscopy (Figs. 1, 2a-c) and with light microscopy of clearings (Fig. $2 \mathrm{~d}-\mathrm{m}$ ) are merged in order to provide a better understanding.

The epidermis consists of alternating long and short cells (Figs. 1a-i, 2a-f, i-l) covered with a layer of epicuticular wax (e.g., Fig. 1a). In general, long cells are tabular shaped with thin, undulating anticlinal walls (Figs. 1c, i, 2i). Intercostal long cells on both leaf blade surfaces often bear dome-shaped papillae that are often organized in one or two central rows (Figs. 1a, c-f, 2a-c, 1), but only scattered papillae may be observed on the abaxial long cells of C. ramosissima (Fig. 1b) and the adaxial ones of $C$. tenuiglumis (Fig. 1g). Papillae are usually absent or poorly developed in the interstomatal band of the intercostal zone in C. ramosissima (Fig. 1b) and C. tenuiglumis (Fig. 1h, i), but often are well developed in C. tenella (Fig. 1e, f) and Chusquea sp. nov. (Fig. 2b).

Short cells may be developed as silica cells or cork cells (Fig. 2g, 1). Silica cells occur in the costal zone on both surfaces and they are associated with tabular short cells (e.g., Fig. 2k), but they also occur scattered on the adaxial surface (sometimes also abaxially) in the intercostal zone (e.g., Figs. 1d, e, 2a, f). In the costal zone (over the veins), silica cells are horizontally oriented (e.g., Fig. 2d, e, j, k), but in the interstomatal band of the intercostal zone, silica cells are always vertically oriented (e.g., Fig. 2f, 1, m). With regard to shape, silica cells are mainly saddle-shaped (e.g., Fig. 2j), but dumbbell-shaped (Fig. 3d, e, k) and irregular-crenate cells (Fig. 2d) can be observed in the same specimen/sample. Also, rarely, intercostal long cells might be silicified forming elongated tabular crenate silica cells (Fig. 2i). Cork cells are tall and narrow and occur as silico-suberose pairs mostly in the intercostal zone (Fig. 2g, 1). 
Table 3 Summary of the main foliar micromorphological and anatomical features of the Chusquea ramosissima informal group: 1. Chusquea ramosissima; 2. C. tenella; 3. C. tenuiglumis; 4. Chusquea sp. nov.

\begin{tabular}{|c|c|c|c|c|}
\hline \multirow[t]{2}{*}{ Features } & \multicolumn{4}{|c|}{ Taxa } \\
\hline & 1 & 2 & 3 & 4 \\
\hline \multicolumn{5}{|l|}{ Surface view } \\
\hline \multicolumn{5}{|l|}{ Epidermis } \\
\hline Silica bodies (costal) horizontally oriented & + & + & + & + \\
\hline Silica bodies (costal) vertically oriented & - & - & - & - \\
\hline Subsidiary cells bearing two branched papillae & + & - & + & - \\
\hline Subsidiary cells bearing two simple papillae & - & + & - & + \\
\hline Subsidiary cells low dome shaped & - & - & - & + \\
\hline Subsidiary cells low triangular shaped & + & + & + & - \\
\hline \multicolumn{5}{|l|}{ Cross section } \\
\hline \multicolumn{5}{|l|}{ Mesophyll } \\
\hline Arm cells with invaginations from the abaxial side & + & + & + & + \\
\hline Arm cells with invaginations from both sides & - & - & - & - \\
\hline \multicolumn{5}{|l|}{ Midrib } \\
\hline Composed of two vascular bundles & + & - & + & + \\
\hline Composed of three vascular bundles & - & + & - & - \\
\hline \multicolumn{5}{|l|}{ Margins } \\
\hline Dimorphic & + & - & - & - \\
\hline Structurally similar & - & + & + & + \\
\hline
\end{tabular}

observed on the abaxial surface of $C$. ramosissima and $C$. tenella (Fig. 2e) Silicified unicellular microhairs occur often on the abaxial surface (rarely adaxially) in C. tenella and Chusquea sp. nov. (Fig. 2a, h), whereas bicellular microhairs occur on the abaxial surface of all the studied species (e.g., Figs. 1b, e, h, 2b).

\section{Cross section}

The outline of the leaf blade as seen in cross section is gently undulated (e.g., Fig. 3a, b). The epidermis consists of a single layer of cells with slightly thickened outer periclinal walls in most of the species (e.g., Fig. 3a, b, d, e). Epidermal cells are all about the same size except for the presence of fan-shaped arrays of bulliform cells in between the bundles as part of the adaxial epidermis (e.g., Fig. 3a, b). The number of bulliform cells in each array is variable among samples within the same species.

The mesophyll comprises asymmetrically invaginated arm cells, fusoid cells, and rosette cells (e.g., Fig. 3a-c). Arm cells are organized in two layers (e.g., Fig. 3a-c), and invaginations of these cells are from the abaxial side (e.g., Fig. 3a-c). Just one layer of arm cells is observed adjacent to the abaxial surface, in which the invaginations are relatively shallow and often occur just from the adaxial side (e.g., Fig. 3a, b). Surrounded by arm cells and adjacent to the vascular bundles, the fusoid cells are highly variable in shape and size among and within 

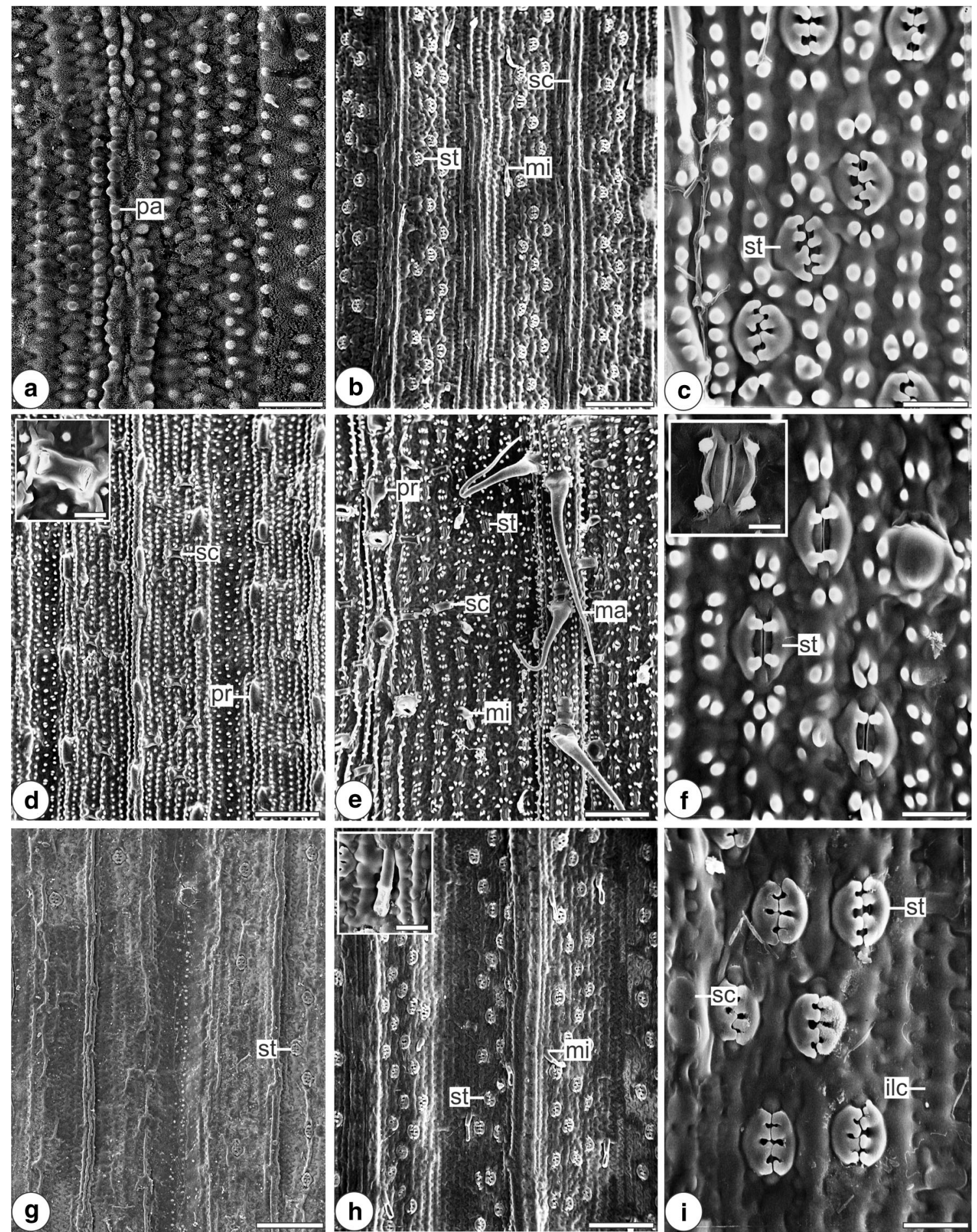

Fig. 1 Micromorphology from SEM of Chusquea ramosissima informal group species. Adaxial surface $(\mathbf{a}, \mathbf{d}, \mathbf{g})$, abaxial surface (b, c, e, f, h, i). a C. ramosissima (Hatschbach 40533); b C. ramosissima (Hatschbach 42746); c C. ramosissima (Soderstrom and Sucre 1986); d C. tenella (Klein and Bresolin 7766, inset Swallen 9004); e C. tenella (Swallen 9004); f C. tenella (Palacios-Cuezzo 474, inset Swallen 9004); g C. tenuiglumis (Clark and Windisch 864). h C. tenuiglumis (Clark and Morel 706, inset Hatschbach 42746); i C. tenuiglumis (Clark and Morel 706). ilc intercostal long cell, ma macrohair, mi microhair, $p a$ papilla, $p r$ prickle, $s c$ silica cell, $s t$ stomatal apparatus. Scale bars $60 \mu \mathrm{m}(\mathbf{a}, \mathbf{b}, \mathbf{d}, \mathbf{e}, \mathbf{g}, \mathbf{h}), 13 \mu \mathrm{m}(\mathbf{c}, \mathbf{f}, \mathbf{i})$, $6.5 \mu \mathrm{m}$ (insets) 

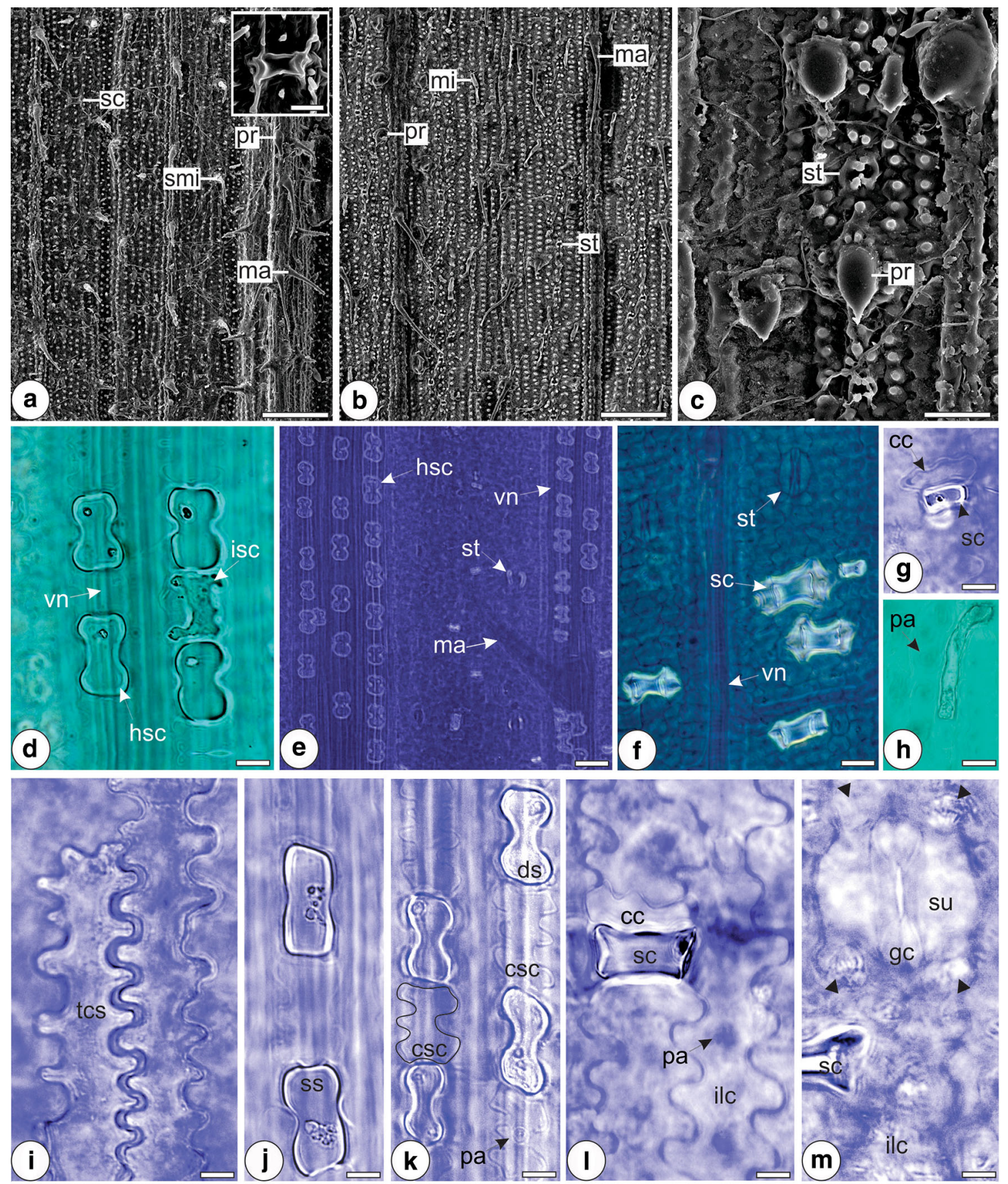

Fig. 2 Micromorphology (SEM) and anatomy (light microscopy) of Chusquea ramosissima informal group species in surface view. Adaxial surface (a, d, f, g, i, l), abaxial (b, c, e, h, j, k, m). a Chusquea sp. nov. (Fuentes et al. 9662, inset Uzquiano et al. 10); b Chusquea sp. nov. (Cayola et al. 6); c Chusquea sp. nov. (Fuentes et al. 9662); d Chusquea sp. nov. (Cayola et al. 6); e C. ramosissima (Clark and Windisch 849); f Chusquea sp. nov. (Uzquiano et al. 10); g Chusquea sp. nov. (Cayola et al. 6); h Chusquea sp. nov. (Fuentes et al. 9662) showing a silicified unicellular microhair; i $C$. tenella (Clark and Windisch 725); j Chusquea sp. nov. (Cayola et al. 6); k C. ramosissima (Clark and Windisch 849); I Chusquea sp. nov. (Cayola et al. 6); m C. ramosissima (Clark and Windisch 849) showing papillae (arrowheads). $c c$ cork cell, $c s c$ costal short cell, $d s$ dumbbell shaped silica cell, gc guard cells, hsc horizontally oriented silica cell, $i l c$ intercostal long cell, isc irregular-crenate silica cell, ma macrohair, $m i$ microhair, $p a$ papilla, $p r$ prickle, sc silica cell, smi silicified unicellular microhair, ss saddle shaped silica cell, st stomatal apparatus, $s u$ subsidiary cell, tcs tabular crenate silica cell, $v n$ vein. Scale bars $5 \mu \mathrm{m}$ (g-m), $6.5 \mu \mathrm{m}$ (inset), $10 \mu \mathrm{m}$ (f), $20 \mu \mathrm{m}$ (d, e), $60 \mu \mathrm{m}(\mathbf{a}, \mathbf{b}), 13 \mu \mathrm{m}(\mathbf{c})$ 
Fig. 3 Anatomy from light microscopy of Chusquea ramosissima informal group species in cross section. a $C$. ramosissima (Hatschbach 42746); b Chusquea sp. nov. (Uzquiano et al. 10); c C. tenella (Klein and Bresolin 9477) showing arm cells with invaginations from the abaxial side; d C. tenuiglumis (Clark and Windisch 864) showing midrib comprising two opposing vascular bundles sharing the same bundle sheath; e C. tenella (Clark and Windisch 725) showing midrib comprising three vascular bundles (two smaller ones opposing the major one), all sharing the same bundle sheath. Arrowhead $=$ stoma. $a c$ arm cell; $b c$ bulliform cell, $f c$ fusoid cell, $p$ phloem, $r c$ rosette cell, $x$ xylem. Scale bars $5 \mu \mathrm{m}(\mathbf{c})$, $10 \mu \mathrm{m}(\mathbf{a}), 15 \mu \mathrm{m}(\mathbf{b}, \mathbf{d}, \mathbf{e})$

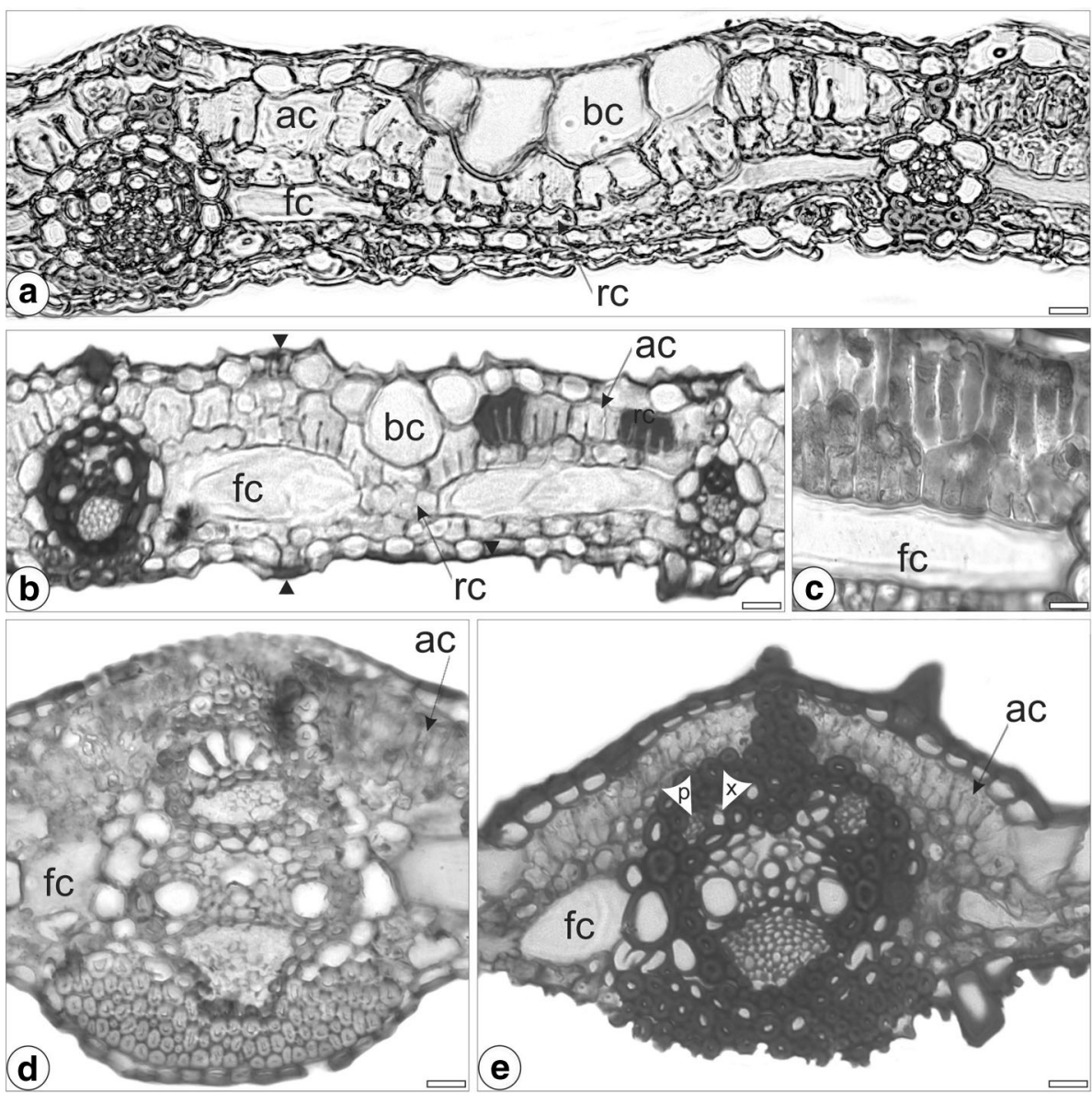

species/specimens (e.g., Fig. 3a-e). These cells occur along the entire lamina, except at the margins. Rosette cells occur between fusoid cells (e.g., Fig. 3a, b), with the number of cells extremely variable in each group along the leaf blade.

With regard to the vascular tissue, xylem and phloem are collateral and surrounded by a double sheath, the inner mestome sheath and the outer parenchymatic sheath (e.g., Fig. 3a, b). Vascular bundles comprise two types: (1) first order with distinguishable metaxylem and phloem (e.g., Fig. 3a, b); and (2) third order, small vascular bundles with usually a few lignified tracheary elements and a small patch of phloem (e.g., Fig. 3a, b). Girders occur in both types of vascular bundles, but only the parenchymatic sheath from the first-order vascular bundles is abaxially interrupted by this arrangement of fibers (e.g., Fig. 3b). The midrib is complex and is composed of one large abaxial and one smaller adaxial opposing vascular bundle (e.g., C. tenuiglumis, Fig. 3d) or one large abaxial and two smaller opposing bundles (C. tenella, Fig. 3e), all sharing the same bundle sheaths.

Leaf blade margins are mainly acute, but one acute and one obtuse margin (dimorphic) may be observed within the same leaf blade of $C$. ramosissima (Table 3). Also, the amount of sclerenchyma cells in this region is variable among species and even within the same sample.

\section{Discussion}

\section{Micromorphological and anatomical data}

At least some long cells with papillae; fan-shaped arrays of bulliform cells; a mesophyll with some strongly invaginated arm cells, fusoid cells, rosette cells, and collateral vascular bundles surrounded by a double sheath; and a $\mathrm{C}_{3}$ photosynthetic pathway are features shared by all the studied species and also are general for Bambusoideae (Metcalfe 1960; Calderón and Soderstrom 1973; Hattersley 1987; Judziewicz et al. 1999; Oliveira et al. 2008; Gomes and Neves 2009; Viana 2010; Mota 2013; Leandro et al. 2016b). This study reveals many anatomical similarities among the sampled species while also demonstrating that micromorphological features, especially those of the stomatal complex, prove to be more systematically informative. Presence or absence of trichomes and their type, shape of silica bodies, type of arm cells, and the midrib structure may be useful at the species level. 


\section{Implications for systematics}

The occurrence of intercostal fibers, presence or absence of papillae on the subsidiary cells and midrib structure seem to be the primary differences between the subtribes Chusqueinae and Arthrostylidiinae (Soderstrom and Ellis 1987; Leandro et al. 2016b). Intercostal fibers and a simple midrib are diagnostic features for Arthrostylidiinae, whereas the Chusqueinae is recognized by the presence of a stomatal apparatus bearing two papillae per subsidiary cell, lack of intercostal fibers, and a complex midrib (Fisher et al. 2009, 2014; Clark et al. 2015). Comparatively, Guaduinae is distinguished from these two subtribes by the adaxial epidermis having abundant stomata and often welldeveloped papillae (Judziewicz et al. 1999; Ruiz-Sanchez et al. 2008; BPG 2012; Clark et al. 2015). Guaduinae also lack intercostal fibers and possess a complex midrib, and both the Arthrostylidiinae and Guaduinae lack any papillae on the subsidiary cells (Clark et al. 2015).

Papillae are considered characteristic of bamboo leaves (Judziewicz et al. 1999), and thus they may be systematically informative for this group (e.g., Calderón and Soderstrom 1973; Gomes and Neves 2009; Zhang et al. 2014; Leandro et al. 2016b); however, in our study, intraspecific variation in the development of papillae is observed in all four species, in which papillae may vary from poorly to well developed (rarely completely absent). For example, $C$. ramosissima specimens herein studied exhibit papillae mostly in the stomatal band, as well as on the adaxial surface, but specimens from Argentina exhibit an epidermis with no papillae on the long cells of either surface (Lizarazu 2013; Montti et al. 2008). Despite this remarkable intraspecific variation, C. ramosissima consistently exhibits a stomatal apparatus bearing two branched papillae (this study and Lizarazu 2013). Because $C$. ramosissima is so widely distributed (Judziewicz et al. 1999), it is perhaps not surprising that it exhibits variation in some features, but it is also possible that some of this variation in papillar development in the species of this group is due to environmental effects (e.g., sun/shade, March and Clark 2011) that have not been explored in this group. Also, we observed that papillar development in $C$. ramosissima and $C$. tenella did not correlate with reproductive state-this is consistent with the fact that we also observed some variation among the specimens of $C$. tenuiglumis and Chusquea sp. nov., which only sterile material was examined.

The stomatal apparatus in Bambusoideae (and Poaceae) is composed of a pair of guard cells surrounded by two paracytic subsidiary cells (Metcalfe 1960; Ellis 1979; Judziewicz et al. 1999). Subsidiary cells bearing two papillae are a feature shared by all the studied species, and it is putatively a synapomorphic character for Chusquea within the woody bamboos, although it is known to occur in Olyreae (Soderstrom and Ellis 1987; Fisher et al. 2009, 2014; Clark et al. 2015). Although the presence of branched papillae on the subsidiary cells has been previously reported for other species of Chusquea (Clark 1986, 1989), the presence of two branched papillae that completely overarch the guard cells herein observed in $C$. ramosissima and $C$. tenuiglumis is highly informative for identifying these two species within this group. However, branched papillae are easily visible only with aid of SEM techniques, and thus the stomatal apparatus of these species may be erroneously interpreted. For instance, based on light microscopy, Montti et al. (2008) reported that the stomatal apparatus of $C$. ramosissima bears refractive papillae, without indicating how many per cell or the structure of the papillae. Refractive papillae were reported, but not adequately defined or described, by Soderstrom and Ellis (1987) for some bamboo groups, but not for Chusqueinae. It is possible that under LM, the papillae of the subsidiary cells appear to be refractive, but in the SEM images (Figs. 1a-i, 2a-c), these papillae do not appear qualitatively different from the papillae of the long cells.

Species herein studied share a complex midrib vasculature as expected for Chusquea (BPG 2012; Clark et al. 2015), although not composed solely of independent vascular bundles. The complex midrib in species of subg. Rettbergia (currently 15 described species) often comprises at least two vascular bundles, each one usually with their own bundle sheaths (except for C. pulchella L.G. Clark and C. sellowii Rupr., in which two bundles share both sheaths) (Mota 2013), and Guerreiro et al. (2014) showed this condition in three species of Chusquea subg. Platonia. In contrast, a midrib composed of one central vascular bundle that shares its own bundle sheaths with one or two opposing vascular bundles is a shared feature among the species herein studied, which are all placed within subg. Chusquea (Fisher et al. 2009). In the $C$. ramosissima informal group, a midrib with a few elements of xylem and phloem embedded in fibers is observed opposite to the abaxial vascular bundle-and sometimes these are difficult to distinguish. For instance, Montti et al. (2008) interpreted the midrib vasculature of $C$. tenella as comprising two opposing vascular bundles; however, two groups of xylem elements can be distinguished in the figure provided by the authors (see Fig. 6D in Montti et al. 2008). The developmental pattern of the midrib vasculature within Chusquea deserves broader study in order to verify its value for systematics across the genus.

All species of the $C$. ramosissima informal group, including Chusquea sp. nov., share horizontally oriented, dumbbell-shaped silica cells over the veins, which was also observed by Montti et al. (2008) and Lizarazu (2013) for $C$. ramosissima and C. tenella. Soderstrom and Ellis (1987) reported that horizontally oriented, dumbbell-shaped silica 
cells over the veins are diagnostic for Chusqueinae and unusual in bamboos generally, with the more typical condition being vertically oriented silica cells. However, although horizontally oriented dumbbell-shaped silica cells over the veins are characteristic of the C. ramosissima informal group and a few other species (e.g., C. coronalis Soderstr. \& C. Calderón, C. juergensii Hack., C. pittieri Hack., C. simpliciflora Munro), many other species of Chusquea show only vertically oriented silica cells over the veins (Clark 1986, 1990; Lizarazu 2013).

Chusquea ramosissima and C. tenuiglumis exhibit branched papillae on the subsidiary cells, but they may be distinguished by the margins (dimorphic or not), and by the number of rows of stomata in the intercostal zone on the abaxial surface (two or three). The stomatal apparatus is also useful for distinguishing C. ramosissima and Chusquea sp. nov., which are morphologically similar, although the relatively wider leaf blades and shorter synflorescences of Chusquea sp. nov. initially suggested that it might deserve recognition as a distinct species. Our results support this, and it is being described as a new species as part of a taxonomic revision of this group. Chusquea tenella and Chusquea sp. nov. are similar in their micromorphology, but $C$. tenella differs from it and the other two species of the group in having three vascular bundles in the midrib rather than just two in addition to differences in leaf blade shape and size and spikelet characters.

\section{Conclusions}

Our results show that horizontally elongated silica cells over the veins and adaxial arm cells with invaginations only from the abaxial side, along with morphological features such as culm leaves with pseudopetiolate, deciduous blades that usually remain green and racemose or weakly paniculate synflorescences (Fisher et al. 2009, 2014) strongly support the recognition of the Chusquea ramosissima informal group. The results also support the recognition of Chusquea sp. nov. from Bolivia as distinct from $C$. ramosissima. Broader foliar anatomical and micromorphological studies within Chusquea are needed, including study of the midrib structure and the potential for environmental effects on micromorphology.

\section{Taxonomic treatment}

Identification key based on micromorphological and anatomical features of the Chusquea ramosissima informal group

1a. Each subsidiary cell bearing two branched papillae (Fig. 1c, i) . 2 1b. Each subsidiary cell bearing two simple papillae (Figs. 1f, 2c)

2a. Leaf blade margins dimorphic, often exhibiting groups of two rows of stomata in the intercostal zone on the abaxial surface

C. ramosissima

2b. Leaf blade margins structurally similar; often exhibiting groups of three rows of stomata in the intercostal zone on the abaxial surface

C. tenuiglumis

3a. Midrib composed of two opposing vascular bundles (e.g., Fig. 3e) Chusquea sp. nov.

3b. Midrib composed of three vascular bundles, two smaller ones opposing the major one (Fig. 3f) ...... C. tenella

General features for the Chusquea ramosissima informal group

Adaxial surface: Long cells tabular with undulate anticlinal walls. Papillae often present on the long cells; often present on the bulliform cells. Short cells over the veins and usually scattered between the veins: silica cells saddle shaped, dumbbell shaped or irregular crenate, horizontally oriented over the veins, vertically oriented in the intercostal zone; cork cells usually present, occurring in silico-suberose pairs in the intercostal zone. Prickles often present. Microhairs often present, unicellular and silicified or bicellular and non-silicified. Macrohairs rarely present (observed in Chusquea sp. nov.), unicellular. Stomata usually absent, if present with subsidiary cells low dome shaped or low triangular shaped; and two papillae per subsidiary cell, branched or simple.

Abaxial surface: Long cells tabular with undulate anticlinal walls. Papillae often present on the long cells. Short cells mainly over the veins. Silica cells saddle shaped, dumbbell shaped, or irregular crenate, horizontally oriented over the veins, vertically oriented in the intercostal zone; cork cells usually present, occurring in silico-suberose pairs in the intercostal zone. Prickles often present. Microhairs often present, unicellular and silicified or bicellular and non-silicified. Macrohairs usually observed in $C$. tenella and Chusquea sp. nov., unicellular. Stomata present in rows in the intercostal zone, subsidiary cells low dome shaped or low triangular shaped, two papillae per subsidiary cell, branched or simple.

Cross section: Bulliform cells adaxially present, organized in fan-shaped arrays. Mesophyll with two layers of asymmetrically invaginated arm cells adjacent to the adaxial epidermis, one layer adjacent to the abaxial epidermis; adaxial arm cells with invaginations from the abaxial side; abaxial arm cells mostly with invaginations from the adaxial side. Fusoid cells always present. Vascular bundles collateral; first and third orders. Midrib complex (comprising more than one vascular bundle), all bundles sharing the same bundle sheaths. Girders always present adjacent 
to the vascular bundles. Margins mainly acute; sometimes acute and obtuse (dimorphic).

\section{Description of each species including only differences from the general condition}

Chusquea ramosissima: Papillae usually well developed on both surfaces, but sometimes poorly developed or absent. Silica cells dumbbell shaped. Prickles absent. Microhairs on both surfaces; bicellular and non-silicified. Macrohairs rarely observed on the abaxial surface; unicellular. Stomatal apparatus with subsidiary cells low triangular shaped; two branched papillae per subsidiary cell. Midrib comprising two opposing vascular bundles. Margins acute and obtuse (dimorphic).

Chusquea tenella: Papillae well developed on both surfaces. Silica cells saddle shaped and dumbbell shaped. Prickles on both surfaces. Microhairs on the abaxial surface; mostly bicellular and non-silicified, less frequently unicellular and silicified. Macrohairs sometimes observed on the abaxial surface; unicellular. Stomatal apparatus with subsidiary cells low triangular shaped; two simple papillae per subsidiary cell. Midrib comprising three vascular bundles; two smaller ones opposing the major one. Margins acute.

Chusquea tenuiglumis: Papillae usually absent from the long cells, rarely present adaxially. Silica cells saddle shaped and dumbbell shaped. Prickles absent. Microhairs rarely observed on the abaxial surface; bicellular, and nonsilicified. Macrohairs absent. Stomatal apparatus with subsidiary cells low triangular shaped; two branched papillae per subsidiary cell. Midrib comprising two opposing vascular bundles. Margins acute.

Chusquea sp. nov.: Papillae well developed on both surfaces. Silica cells mostly dumbbell-shaped, and also irregular crenate. Prickles on both surfaces. Microhairs on both surfaces; bicellular and non-silicified. Macrohairs on both surfaces; unicellular. Stomatal apparatus with subsidiary cells low dome shaped; two simple papillae per subsidiary cell. Midrib comprising two opposing vascular bundles. Margins acute.

\footnotetext{
Acknowledgements This research was completed as a partial fulfillment for the first author's scholarship funded by the Coordenação de Aperfeiçoamento de Pessoal de Nível Superior-CAPES (PDSE Process Number 99999.003340/2015-05) and the Conselho Nacional de Desenvolvimento Científico e Tecnológico-CNPq (GD Process Number 163550/2012-3). V.L. Scatena was supported by the Conselho Nacional de Desenvolvimento Científico e Tecnológico- $-\mathrm{CNPq}$ (Process Number 301692/2010-6). Field work and SEM by L.G. Clark was supported by U.S. National Science Foundation Grant BSR-8906340. The authors are grateful to Dr. Harry T. Horner and Tracey M. Stewart for their assistance and also for access to the Microscopy and Nano-Imaging Facility at Iowa State University.
}

\section{References}

Aliscioni SS, Ospina JC, Gomiz NE (2016) Morphology and leaf anatomy of Setaria s.l. (Poaceae: Panicoideae: Paniceae) and its taxonomic significance. Pl Syst Evol 302:173-185. doi:10.1007/ s00606-015-1251-9

Bamboo Phylogeny Group (BPG) (2012) An updated tribal and subtribal classification of the bamboos (Poaceae: Bambusoideae). Bamboo Sci Cult 24:1-10

Calderón CE, Soderstrom TR (1973) Morphological and anatomical of the grass subfamily Bambusoideae based on the new genus Maclurolyra. Smithsonian Contr Bot 11:1-59

Clark LG (1986) Systematics of Chusquea section Chusquea, section Swallenochloa, section Verticillatae, and section Serpentes (Poaceae: Bambusoideae). PhD Thesis, Iowa State University, Ames

Clark LG (1989) Systematics of Chusquea section Swallenochloa, section Verticillatae, section Serpentes, and section Longifoliae (Poaceae-Bambusoideae). Syst Bot Monogr 27:1-127

Clark LG (1990) Chusquea sect. Longiprophyllae (Poaceae: Bambusoideae): a new Andean section and new species. Syst Bot 15:617-634

Clark LG (2004) New species of Aulonemia and Chusquea (Poaceae: Bambusoideae: Bambuseae) from southeastern Brazil. Revista Brasil Bot 27:31-36. doi:10.1590/S0100-84042004000100004

Clark LG, Davidse G, Ellis RP (1989) Natural hybridization in bamboos: evidence from Chusquea sect. Swallenochloa (Poaceae: Bambusoideae). Natl Geogr Res 5:459-476

Clark LG, Londoño X, Ruiz-Sanchez E (2015) Bamboo taxonomy and habitat. In: Liese W, Köhl M (eds) Bamboo: the plant and its uses. Tropical forestry, vol 10. Springer, Cham, pp 1-30. doi:10. 1007/978-3-319-14133-6_1

Dávila P, Clark LG (1990) Scanning electron microscopy survey of leaf epidermis of Sorghastrum (Poaceae: Andropogoneae). Amer J Bot 77:499-511. doi:10.2307/2444384

de Pelegrin CMG, Longhi-Wagner HM, de Oliveira PL (2009) Anatomia foliar como subsídio à taxonomia de espécies do Complexo Briza L. (Poaceae: Pooideae: Poeae). Acta Bot Brasil 23:666-680. doi:10.1590/S0102-33062009000300006

Ellis RP (1976) A procedure for standardizing comparative leaf anatomy in the Poaceae. I. The leaf-blade as viewed in transverse section. Bothalia 12:65-109. doi:10.4102/abc.v12i1.1382

Ellis RP (1979) A procedure for standardizing comparative leaf anatomy in the Poaceae. II. The epidermis as seen in surface view. Bothalia 12:641-671. doi:10.4102/abc.v12i4.1441

Fisher A, Triplett JK, Ho C-S, Schiller A, Oltrogge K, Schroder E, Kelchner SA, Clark LG (2009) Paraphyly in the bamboo subtribe Chusqueinae and a revised infrageneric classification for Chusquea. Syst Bot 34:673-683. doi:10.1600/036364409790139790

Fisher AE, Clark LG, Kelchner SA (2014) Molecular phylogeny estimation of the bamboo genus Chusquea (Poaceae: Bambusoideae: Bambuseae) and description of two new bamboo subgenera. Syst Bot 39:829-844. doi:10.1600/036364414X681554

Gomes DMS, Neves LJ (2009) Scanning electron microscopy of the leaf epidermis of Merostachys Spreng. (Poaceae: Bambusoideae). Acta Bot Brasil 23:516-525. doi:10.1590/S010233062009000200023

Guerreiro C, Rúgolo de Agrasar ZE, Rodríguez MF (2013) A contribution to the identification of vegetative Andean woody bamboos in southernmost America using leaf anatomy. Bull Torrey Bot Club 140:259-268. doi:10.3159/TORREY-D-1200065.1

Guerreiro C, Oliveira JJA, de Agrasar ZER, Beck SG, Vega AS (2014) Two new species and synopsis of Chusquea subg. 
Platonia (Poaceae: Bambusoideae: Chusqueinae) in Bolivia and a new record for Peru. Phytotaxa 183:224-238. doi:10.11646/ phytotaxa.183.4.2

Guglieri A, Longhi-Wagner HM, Zuloaga FO (2008) Anatomia foliar das espécies de Panicum L. subg. Panicum (Poaceae: Panicoideae: Paniceae) no Brasil. Iheringia Bot 63:279-293

Hattersley PW (1987) Variations in photosynthetic pathway. In: Soderstrom TR, Hilu KW, Campbell CS, Barkworth ME (eds) Grass systematics and evolution. Smithsonian Institution Press, Washington

Janzen DH (1976) Why bamboos wait so long to flower. Annual Rev Ecol Syst 7:347-391

Johansen DA (1940) Plant microtechnique. McGraw Hill, New York

Judziewicz EJ, Clark LG, Londoño X, Stern MJ (1999) American bamboos. Smithsonian Institution Press, Washington, p 392

Kelchner SA, Bamboo Phylogeny Group (BPG) (2013) Higher level phylogenetic relationships within the bamboos (Poaceae: Bambusoideae) based on five plastid markers. Molec Phylogen Evol 67:404-413. doi:10.1016/j.ympev.2013.02.005

Leandro TD, Scremin-Dias E, Arruda RCO (2016a) Micromorphology and anatomy of the leaf blade: a contribution to the taxonomy of Luziola (Poaceae, Oryzoideae) from the Pantanal, Brazil. Pl Syst Evol 302:265-273. doi:10.1007/s00606-0151260-8

Leandro TD, Shirasuna RT, Filgueiras TS, Scatena VL (2016b) The utility of Bambusoideae (Poaceae, Poales) leaf blade anatomy for identification and systematics. Brazil J Biol 76:708-717. doi:10.1590/1519-6984.01715

Lizarazu MA (2013) Bambúes leñosos (Poaceae: Bambusoideae: Bambuseae) del Noreste argentino y regiones limítrofes: estudos taxonómicos, morfológicos, anatómicos y biogeográficos. $\mathrm{PhD}$ Thesis, Instituto de Botánica Darwinion, Buenos Aires

March RH, Clark LG (2011) Sun-shade variation in bamboo (Poaceae: Bambusoideae) leaves. Telopea 13:93-104

Metcalfe CR (1960) Anatomy of the Monocotyledons I: Gramineae. Claredon Press, Oxford

Montti L, Graciano Riveiro D, Goldstein G (2008) Anatomical traits of woody bamboos for taxonomic identification: a case study in neotropical species. J Bamboo Rattan 7:1-20

Montti L, Honaine MF, Osterrieth Ribeiro DG (2009) Phytolith analysis of Chusquea ramosissima Lindm. (Poaceae: Bambusoideae) and associated soils. Quatern Int 193:80-89. doi:10. 1016/j.quaint.2007.11.024

Mota da AC (2013) Sistemática de Chusquea subgênero Rettbergia (Bambusoideae, Poaceae). PhD Thesis, Universidade Estadual de Feira de Santana, Feira de Santana

Oliveira RP, Longhi-Wagner HM, Leite KRB (2008) A contribuição da anatomia foliar para a taxonomia de Raddia Bertol. (Poaceae: Bambusoideae). Acta Bot Brasil 22:1-19. doi:10.1590/S010233062008000100002

Richter HG (1985) Wood and bark anatomy of Lauraceae II. Licaria Aublet. Iawa Bull 6:187-199

Ruiz-Sanchez E (2011) Biogeography and divergence time estimates of woody bamboos: insights in the evolution of Neotropical bamboos. Bol Soc Bot México 88:67-75. doi:10.17129/botsci. 312

Ruiz-Sanchez E, Sosa V, Mejía-Saules MT (2008) Phylogenetics of Otatea inferred from morphology and chloroplast DNA sequence data, and recircumscription of Guaduinae (Poaceae: Bambusoideae). Syst Bot 33:277-283. doi:10.1600/ 036364408784571644

Ruiz-Sanchez E, Peredo LC, Santacruz JB, Ayala-Barajas R (2017) Bamboo flowers visited by insects: do insects play a role in the pollination of bamboo flowers? Pl Syst Evol 303:51-59. doi:10. 1007/s00606-016-1351-1

Seifriz W (1950) Gregarious flowering of Chиsquea. Nature 165:635-636. doi:10.1038/165635a0

Soderstrom TR, Ellis RP (1987) The position of bamboo genera and allies in a system of grass classification. In: Soderstrom TR, Hilu KW, Campbell CS, Barkworth ME (eds) Grass systematics and evolution. Smithsonian Institution Press, Washington, pp 225-238

Spurlock BO, Skinner MS, Kattine AA (1966) A simple rapid method for staining epoxy-embedded specimens for light microscopy with the polychromatic stain paragon-1301. Amer J Clinical Path 46:252-258. doi:10.1093/ajcp/46.2.252

Sungkaew S, Stapleton CMA, Salamin N, Hodkinson TR (2009) Nonmonophyly of the woody bamboos (Bambuseae; Poaceae): a multi-gene region phylogenetic analysis of Bambusoideae s.s. J Pl Res 122:95-108

Tyrrell CD, Santos-Gonçalves AP, Londoño X, Clark LG (2012) Molecular phylogeny of the arthrostylidioid bamboos (Poaceae: Bambusoideae: Bambuseae: Arthrostylidiinae) and new genus Didymogonyx. Molec Phylogen Evol 65:136-148. doi:10.1016/j. ympev.2012.05.033

Vega AS, Castro MA, Guerreiro C (2016) Ontogeny of fusoid cells in Guadua species (Poaceae, Bambusoideae, Bambuseae): evidence for transdifferentiation and possible functions. Flora 222:13-19

Viana PL (2010) O gênero Aulonemia Goudot (Poaceae: Bambusoideae: Bambuseae) no Brasil. $\mathrm{PhD}$ Thesis, Universidade Federal de Minas Gerais, Belo Horizonte

Wong KM, Goh WL, Chokthaweepanich H, Clark LG, Sungkaew S, Widjaja E, Xia N-H (2016) A subtribal classification of Malesian and South Pacific woody bamboos (Poaceae: Bambusoideae: Bambuseae) informed by morphological and molecular studies. Sandakania 22:11-36

Wysocki WP, Clark LG, Attigala L, Ruiz-Sanchez E, Duvall MR (2015) Evolution of the bamboos (Bambusoideae; Poaceae): a full plastome phylogenomic analysis. BCM Evol Biol 15:50. doi: 10.1186/s12862-015-0321-5

Zhang Y-X, Zeng C-X, Li D-Z (2014) Scanning electron microscopy of the leaf blade epidermis in Arundinarieae (Poaceae: Bambusoideae): evolutionary implications of selected micromorphological features. Bot J Linn Soc 176:46-65. doi:10.1111/boj. 12192 